Biografistyka Pedagogiczna

Rok 1 (2016) nr 1

ISSN 2543-6112; e-ISSN 2543-7399

DOI: 10.36578/BP.2016.01.07

Paweł Skrzydlewski ${ }^{\star}$

\title{
Władysław Tatarkiewicz - logos i ethos wychowawcy polskiej inteligencji
}

\section{Władysław Tatarkiewicz: The Logos and Ethos of the Teacher of Polish Intelligentsia}

\begin{abstract}
This article portrays the life of Professor Władysław Tatarkiewicz and his life's influence on his intellectual development, as well as his moral and intellectual choices. He was an educator and a teacher of many generations of Polish intellectuals. His works in the field of ethics, history of philosophy and aesthetics are great intellectual treasures of Polish culture. To date, little has been known about the role that the Catholic religion and Polish national culture played in his intellectual development. The life of Professor Tatarkiewicz was complex, varied, morally beautiful and embedded in Polish culture and national Catholic tradition. He came from a family of landowners and graduated from a classic high school in Warsaw at the age of seventeen. When studying Greek and Latin classical literature, he liked the Greek ideal of kalokagathia. He became interested in art, architecture, aesthetics and philosophy. As he wrote, 'I grew up in a religious family. As a child and later, I treated the truths of faith on equal terms as the facts of the surrounding world. They did not make my life easier, but sometimes I think that religious faith is something we should get by ourselves rather than inherit' (Wspomnienia, p. 120).
\end{abstract}

Keywords: Władysław Tatarkiewicz, history of philosophy, ethics, biography, national and Catholic traditions

* Paweł Skrzydlewski - dr hab., prof. Państwowej Wyższej Szkoły Zawodowej w Chełmie i wykładowca w Akademii Ignatianum w Krakowie, pskrzydl@gmail.com. 
Droga życia profesora Władysław Tatarkiewicza (ur. 3 kwietnia 1886 r. w Warszawie, zm. 4 kwietnia 1980 r. tamże) była złożona, bogata, moralnie piękna, a w swojej treści osadzona w polskości i tradycji narodowej, katolickiej. Zasadniczą rolę w formacji Tatarkiewicza odegrało obok domu rodzinnego, żyjącego kulturą szlachecką, ziemiańską - klasyczne gimnazjum. Ukończył je w Warszawie w wieku lat siedemnastu. Przez zapoznanie się z greką, łaciną oraz literaturą klasyczną rozmiłował się w greckim ideale kalokagatheii. Tam też swoją uwagę zwrócił ku sztuce, architekturze oraz rozważaniom z dziedziny estetyki i filozofii. Jak pisał:

Wychowałem się w domu wierzącym. Prawdy wiary były dla mnie w dzieciństwie i później taką samą rzeczywistością jak fakty otaczającego mię świata. Niemało ułatwiły mi życie - choć czasem myślę, że wiara religijna jest rzeczą, którą należy samemu zdobyć, a nie dziedziczyć.

Trzeba tu zaznaczyć, że rodzina przyszłego profesora była wyjątkową, dostojną, wręcz arystokratyczną. Nie brakowało w niej artystów, prawników, uczonych, a przede wszystkim patriotów. Jak pisał profesor:

W początkach mego życia wszystko działo się wcześnie i prędko. Miałem równo 17 lat, gdy otrzymałem maturę. O rok wcześniej drukowałem pierwszy wiersz (jeden z nielicznych) w Chimerze. Byłem zaledwie pełnoletni, gdy zostałem przyjęty na audiencji przez Ojca Św:; a była to prawdziwa audiencja, osobista na kilka osób i we frakach. Miałem lat 23, gdy uzyskałem doktorat i gdy ukazała się na zachodzie moja dość duża i dość uczona książka o Arystotelesie. W wieku lat 29 znalazłem się na katedrze uniwersyteckiej. [...] miałem 41 lat, gdy zostałem profesorem zwyczajnym, 44gdy członkiem Akademii Umiejętności. A w końcu doszedłem do liczb niezwykle wysokich: jedną z mych książek napisałem w dziewięćdziesiątym roku życia².

W dzieciństwie oraz wczesnej młodości środowiskiem życia Tatarkiewicza obok Warszawy były dworki rodzinne, szlacheckie, (Bełżyce koło Lublina, Krzywowola koło Rejowca, także Nałęczów). Spędzał tam nie mało czasu przed maturą, wrastając w życie wiejskie i zarazem szlacheckie, ciągle żyjące pamięcią powstań narodowych, walki o suwerenną i niepodległą ojczyznę. Jak sam wspominał, wakacje były także cza-

1 T. i W. Tatarkiewiczowie, Wspomnienia, Warszawa 1979, s. 120.

2 Tamże, s. 117-118. 
sem licznych wycieczek, wypraw w góry (Zakopane) oraz nad morze (Kołobrzeg), ale przede wszystkim czasem zawiązywania więzi rodzinnych.

To wszystko sprawiło, że przyszły profesor nie tylko znał i przeżywał Polskę w jej bogactwie i różnorodności, ale że ją szczerze i do końca swych dni miłował. Miłość swoją ku Polsce wyraził przede wszystkim przez intelektualną pracę, dając filozoficzne i estetyczne podwaliny pod wykształcenie inteligencji polskiej. Zadanie to osiągnął. Potwierdzeniem tego jest nie tylko oparcie Polaków wykształcenia na jego pracach, ale także słowa kardynała Stefana Wyszyńskiego, który w liście do syna profesora Krzysztofa, w dniu pogrzebu Tatarkiewicza pisał: „My wszyscy w szeregach katolickich: biskupi, kapłani, alumni seminariów duchownych uważamy się za uczniów zasłużonego Profesora".

Tatarkiewicz po uzyskaniu matury, pragnął zdobyć wykształcenie techniczne, praktyczne. Toteż próbował w latach 1903-1905 w Warszawie studiów matematycznych oraz prawniczych, których jednak z przyczyn losowych (historycznych) nie mógł ukończyć, ale też i nie chciał. Jak pisał:

[...] matematyka tak mnie nudziła, że wytrzymałem tylko trzy tygodnie. Przeniosłem się na wydział prawa. Nie dlatego bym miał szczególne powołanie do studiów prawniczych, lecz że na tym wydziale byli koledzy, których najbardziej lubiłem. Jedyna rzecz, na którą naprawdę miałbym wtedy ochotę, to - hodować konie, ale na to nie byłem dość bogaty. Przeszedłem na drugi rok prawa, ale był to rok 1905, rok burzliwy. Zaczął się wiecem, domagającym się języka polskiego w szkołach wyższych. Po tym dramatycznym wiecu uniwersytet został zamknięty, a ja straciłem prawa studenta. I znów stało się coś złego, co mi na dobre wyszło. [...]. W ciągu półtora roku mego studium prawniczego nie całkowicie jednakże traciłem czas. Wykłady uniwersyteckie mię nie interesowały, za to chodziłem na tajne, przede wszystkim na wykłady filozofii i psychologii Adama Mahrburga. Te zakonspirowane wykłady były zapewne najlepszymi z tych wszystkich, jakich słuchałem w życiu. Ale chodziłem na nie jakby dla przyjemności, tak jak się chodzi na koncert czy do teatru, ani mi w głowie nie postało, że sam będę kiedy filozofię wykładać3.

Refleksją filozoficzną zainspirował Tatarkiewicza jeszcze w Warszawie Adam Mahrburg. To być może sprawiło, że zaczął szukać wykształcenia filozoficznego oraz wyjechał z Polski. Było to jednak wykształcenie szerokie i przekraczające wiedzę

3 Tamże, s. 122-123. 
filozoficzną i humanistyczną. W Zurychu w Szwajcarii, gdzie przyjaźnił się z Władysławem Korniłowiczem (przyszłym kapłanem i wybitnym kaznodzieją), planował zdobyć wykształcenie zawodowe, dające mu szansę na pracę w rolnictwie lub w przemyśle chemicznym. Jednakże po jednym semestrze studiów w Szwajcarii w 1905 r. udał się na uniwersytet w Berlinie, gdzie miał możność słuchania wykładów z wielu dziedzin (chemia, psychologia eksperymentalna, historia sztuki, anatomia, psychiatria). $\mathrm{Na}$ studiach spędził dwa lata. Tam też znaczący wpływ na jego formację filozoficzną wywarli profesorowie Georg Simmel oraz Max Dessoir, a także ogólna atmosfera intelektualna i kulturowa Berlina, na którą składały się jego wizyty w muzeach, wystawach, teatrach czy udział w koncertach.

Po dwóch latach pobytu w Berlinie Tatarkiewicz, nie mogąc odnaleźć dla siebie właściwego przedmiotu studiów, zmęczony duchowo, przeniósł się do Marburga, gdzie funkcjonowała słynna już na całą Europę grupa filozofów nawiązujących do twórczości Immanuela Kanta (Paula Natorp, Hermann Cohen, Nicolai Hartman). Nie stał się jednak kantystą, wolał studiować w języku greckim Platona i Arystotelesa. Tam też w 1910 r. uzyskał stopień doktora filozofii, pisząc pracę poświęconą podstawowym pojęciom w filozofii Arystotelesa. Praca ta oceniona została przez Williama Davida Rossa, jednego z najlepszych znawców twórczości Arystotelesa, jako wyjątkowo wybitna. Po dziś dzień jest ważnym wprowadzeniem do studiów nad twórczością Stagiryty.

Sam Tatarkiewicz, oceniając w tym okresie swoje studia, podkreślał, że były one

[...] chaotyczne, przypadkowe, nie kierowane. Dowiedziałem się w ich toku, jak niektórzy filozofowie uprawiają naukę, ale żaden mi nie poradził jak ja mam ją uprawiać; [...]. Mych mistrzów podziwiałem, ale nie miałem najmniejszej ochoty iść ich torem. Skończyłem studia, ale nie zdobyłem programu na przyszłość. Wina była mych profesorów, ale także i moja. Po doktoracie pojechałem jeszcze do Lwowa; chciałem się dowiedzieć, jak pracują Polacy. Od razu przekonałem się, że pracują inaczej i lepiej: szkoła Twardowskiego uczyła właśnie, jak pracować naukowo [....] odpowiadała mi bardziej niż innych zachodnich profesorów4.

Warto w tym kontekście nadmienić, że Tatarkiewicz pod koniec życia sam też przyznawał, że bliżej mu intelektualnie było do Platona i Arystotelesa, myśli średniowiecznej i renesansowej, a także do Pascala niż do Kanta i nowożytnego sposobu filozofowania, przesyconego relatywizmem, subiektywizmem, idealizmem i aprioryzmem. Był 
jednak świadom, że nie wybudował samodzielnie jakiegoś metafizycznego systemu bo jak sądził nie miał ku temu ani zdolności, ani intelektualnej ochoty. Jak krytycznie pisał o sobie i swojej twórczości:

Jeśli nawet mam uzdolnienia naukowe, to raczej inne niż filozoficzne. Jeżeli zaś mam filozoficzne, to nie tego rodzaju, jakiego ogół od filozofów oczekuje. Rozważania nad bytem i wszechświatem napełniają mię zarówno lękiem, jak nieufnością. Zajmowałem się - jako historyk - tym, co wielcy myśliciele sądzili o bycie i wszechświecie, ale to co innego niż wypowiadać się samemu. Jeżeli sam się wypowiadałem o świecie, to tylko o jego niektórych własnościach $\mathrm{i}$ wartościach: moralnych i estetycznych, usiłując je uprościć i rozwikłać; jednakże myśli mych nigdy nie rozwijałem w system. Pisząc o najogólniejszych kategoriach etyki i estetyki, dawałem ich przykłady, ale w system ich nie zebrałem. Nie odbiera mi to jeszcze prawa do tytułu filozofa: boć tak nazywa się nie tylko tych, co formują teorię bytu, ale także tych, co dowodzą, że tej teorii uformować niepodobna. Za filozofów byli zawsze uważani także pozytywiści [...]. Wszakże nie twierdzę, jak oni, że „niepodobna” uformować ogólnej teorii bytu, lecz tylko, że ja nie umiałem takiej teorii uformować i nie umieli też ci myśliciele dalecy i bliscy, których znam. I nie twierdzę - jak to czynili klasyczni pozytywiści -że wiedza nasza ogranicza się do jednostkowych faktów ${ }^{5}$.

W latach 1911-1912 Tatarkiewicz przebywał w Paryżu, gdzie pogłębiał swoje studia nad sztuką i literaturą, ale także miał możność słuchania Henriego Bergsona i Pierre'a Janeta, słynnych w tym czasie postaci francuskiego świata filozoficznego.

Po powrocie do kraju w 1913 r. Tatarkiewicz nawiązał współpracę z W. Weryhą w Warszawie, a następnie grupą lwowskich historyków sztuki, gdzie pod redakcją Tadeusza Piniego ukazywała się Historia malarstwa polskiego. Tatarkiewicz tamże prezentował dorobek polskiej sztuki XIX w. Miał także tuż przed wybuchem pierwszej wojny światowej w Warszawie serię wykładów z filozofii w ramach kursu pedagogicznego Mikołajewskiego oraz kursu Katolickiego Związku Kobiet. Angażował się też mocno w organizację życia naukowego Warszawy oraz upowszechnianie wiedzy filozoficznej i artystycznej.

W 1915 r., po utworzeniu polskojęzycznego Uniwersytetu Warszawskiego, Tatarkiewicz otrzymał propozycję prowadzenia wykładów z historii filozofii i tamże stał się obok Tadeusza Kotarbińskiego, Jana Łukasiewicza wykładowcą nowo powstałej uczelni. Wykłady pozwoliły mu przygotować Historię filozofii, która, ukazując się drukiem po raz pierwszy w 1931 r., stała się kuźnią jego stylu filozofowania i samego pisarstwa.

5 Tamże, s. 182. 
Dzieło to, ostatecznie rozbudowane do trzech tomów, zostało dokończone po drugiej wojnie światowej. Stało się obok jego Historii estetyki fundamentem wykształcenia wielu pokoleń Polaków, ale także po przetłumaczeniu na języki obce - cennym wkładem w rozwój znajomości dziejów myśli filozoficznej na świecie.

Nieocenionym walorem całej twórczości profesora stała się jej jasność i prostota, będąca owocem intensywnej pracy i szacunku dla odbiorcy, a także przekonania o tym, że prawda jest zawsze komunikowalna, choć trudno ją niekiedy przedstawić drugiemu człowiekowi. Jak pisał profesor:

Za mój obowiązek pisarza mam przede wszystkim: wyłożyć rzecz prosto i jasno. Uważam za ciężki zarzut, gdy mi ktoś powie, że mnie nie zrozumiał. Bo raz jeszcze to powtórzę: aby twierdzenie czy pojęcie przeszło z umysłu piszącego [...] do umysłu czytającego [...], musi być dokonana pewna praca, a sądzę, że jest lepiej, gdy ją wykona piszący.

W 1919 r. Tatarkiewicz poślubił Teresę z Potworowskich, niezwykłej urody szlachciankę z Podlasia, osobę gruntownie wykształconą i religijną, znającą biegle kilka języków, pełną pogody ducha i radości życia. Jej rodzinny majątek w Radoryżu koło Łukowa, stał się na pewien czas szczęśliwym domem młodych małżonków. Małżonka jego była wierną towarzyszką życia intelektualnego i zawodowego, pracy i miłości. Przez cały okres życia była jego radością i podporą, przyjaciółką najserdeczniejszą i powierniczką spraw wszelkich. Fakty te należy podkreślić z wielu racji. Miłość, jaka związała i umacniała Tatarkiewiczów - nie bez bólu, pozwoliła im w pokoju znieść trudności i tragedie, których nie oszczędziło im życie (czas okupacji; spalenie domu wraz z całym dobytkiem i pamiątkami w czasie Powstania Warszawskiego; wygnanie z Warszawy przez Niemców; ograbienie, ruina oraz utrata rodzinnej posiadłości Radoryż; odsunięcie przez komunistów na szereg lat profesora od nauczania, a także usuwanie z księgarń i bibliotek jego prac).

W 1919 r. Tatarkiewicz obronił rozprawę habilitacyjną i na okres dwóch lat, czyli do 1921 r. przeniósł się do Wilna, aby na Uniwersytecie Stefana Batorego, już jako profesor, objąć katedrę. Tam też nawiązał współpracę, a także serdeczne więzi z gronem profesorów, do których należeli: Ferdynand Ruszczyc, Marian Zdziechowski, Stanisław Kościałkowski, Marian Massonius, Feliks Koneczny oraz ks. Kazimierz Zimmerman, Wincenty Lutosławski.

6 Tamże, s. 175 . 
W 1921 r. profesor wraz małżonką przeniósł się do Poznania, na tamtejszy uniwersytet, aby objąć posadę kierownika Katedry Estetyki i Najnowszej Historii Sztuki (1921-1923). Pobyt ten jednak nie trwa długo, bo jesienią 1923 r. powrócił do Warszawy, aby podjąć wykłady z historii filozofii oraz historii sztuki i estetyki na Uniwersytecie Warszawskim. W tym czasie podjął się też pracy organizacyjnej i popularyzatorskiej w nauce, od 1924 r. był redaktorem naczelnym „Przeglądu Filozoficznego”.

Czas po pierwszej wojnie światowej był okresem jego intensywnej pracy na polu historii sztuki i filozofii, a także licznych wyjazdów naukowych. To czas nawiązywania współpracy z towarzystwami naukowymi całego świata, poznawania środowisk uniwersyteckich zarówno w Europie, jak i Ameryce Północnej. To lata niezwykłego i przebogatego życia intelektualnego i duchowego na polu całej kultury. Wszystko to dokonywało się nie tylko dzięki dyscyplinie pracy profesora, jego zaradności i pomysłowości, ale także biegłej znajomości języków, którą zachował do końca swoich dni. (Profesor mógł przeprowadzić wykład i dyskusję po polsku, angielsku, francusku, niemiecku, włosku czy rosyjsku, a jego biegłość językowa i jasność umysłu nie opuściła go nawet po dziewięćdziesiątym roku życia).

Jak wspomina profesor w okresie międzywojnia:

Na wykłady i zjazdy naukowe często jeździłem za granicę, więc i tam zebrało się niemało znajomych. Były to znajomości różnej bliskości i nasilenia. Sporo znakomitych ludzi znałem głównie z widzenia, jak Crocego, Lachelier'a czy Le Roy, Wilamowitza, Möllendorf a czy Diltheya: słuchałem ich wykładów czy spotykałem ich na zebraniach. Rozmawiałem ze znakomitościami: dłużej z Bergsonem czy Ortegą, poetą Paul Fort'em czy rzeźbiarzami Bourdelle'm i Maillolem. Znałem bliżej sławnych ludzi. By się ograniczyć do filozofów: znałem długo i dobrze twórców Szkoły Marburskiej: Cohena i Natorpa, Cassirera i Nicolai Hartmanna, nie mówiąc o Polakach: Twardowskim, Mahrburgu, ks. Konstantym Michalskim. Znałem - w luźniejszym rozumieniu wyrazu - wszystkich chyba znaczniejszych filozofów, historyków sztuki i estetyków świata z powojennego ćwierćwiecza, spotykając się z nimi corocznie na zebraniach międzynarodowych organizacji. Kolegowałem na wydziałach uniwersyteckich lub w Akademii z tak wybitnymi jak: Tadeusz Zieliński i Wacław Sierpiński, Stanisław Leśniewski i Stefan Mazurkiewicz, Juliusz Kleiner i Adam Krzyżanowski, z tak znanym i niecodziennym jak Wincenty Lutosławski. Od roku 1915 - przez tyle lat! - byliśmy na sąsiednich katedrach z Tadeuszem Kotarbińskim. Znałem dobrze lub dość dobrze najpierwszych polskich pisarzy mej epoki, Prusa i Żeromskiego, Staffa, Lechonia i Leśmiana, Dąbrowską i Nałkowską. Przyjaźniłem się ze starszymi ode mnie Marianem Massoniusem filozofem, Janem Boloiz-Antoniewiczem - historykiem sztuki, i Eugeniuszem 
Romerem - geografem, a także z również nie żyjącymi już rówieśnikami: z filozofami - Romanem Ingardenem, Florianem Znanieckim i Czesławem Znamierowskim; z Zygmuntem Batowskim i Tadeuszem Mańkowskim - historykami sztuki; z Edwardem Wittigiem i Augustem Zamoyskim - rzeźbiarzami; Kazimierzem Wierzyńskim, ks. Władysławem Korniłowiczem, z czołowym filozofem Niemiec - Heinzem Heimsoethem. Spośród żyjących najdawniejsze przyjacielskie stosunki - od 75 lat - łączą mnie z doktorem praw Adamem Nagórskim.

W okresie międzywojennym profesor Tatarkiewicz pracował także nad poprawą oświaty narodowej. Pracy tej także nie zaniechał w czasie okupacji Warszawy, prowadząc tajne komplety. Było to przyczyną jego prześladowań ze strony okupantów, oraz po drugiej wojnie światowej ze strony władz komunistycznych i wysługujących się im kolaborantów.

Jak sam Tatarkiewicz o tamtych czasach pisał:

Byłem od 1935 r. prezesem zarządu głównego ogólnopolskiego Towarzystwa Nauczycieli Szkół Wyższych i Średnich, wspaniałej instytucji, której oczywiście nie mogli wybaczyć okupanci: już w listopadzie 1939 r. zostałem wezwany do Gestapo na Szucha. Miałem ich zawieść do siedziby Towarzystwa (w Alejach Ujazdowskich). Oficer wrzeszczał, gdy klucz się zaciął. Potem znowu: zobaczywszy na ścianie mapę Polski Romera - gdzie jest indeks do niej? krzyczał robiąc rewizję. Oczywiście musieliśmy opuścić naszą siedzibę, ale robiliśmy swoje dalej. Pamięci ofiar spośród kolegów została poświęcona później tablica w kościele św. Anny. Z trzech wiceprezesów Stefan Kwiatkowski został rozstrzelany w Palmirach jeszcze jesienią 1939, później drugi - Bolesław Pochmarski, a przed samym końcem trzeci, niezapomniany Tadeusz Mikułowski. Jakimś szczęśliwym trafem śmierć mnie ominęła; z dawnego prezydium zostaliśmy tylko we dwóch z Maksymilianem Tazbirem. Przekazaliśmy sprawy i majątek Towarzystwa już wiosną 1945 r. Czesławowi Wycechowi dla Związku Nauczycielstwa Polskiego ${ }^{8}$.

Tragiczny w skutkach okazał się czas Powstania Warszawskiego, który opisywał profesor tymi słowami:

[...] zaczął strzałami do drzwi i okien dobijać się oddział własowców. Byliśmy przygotowani, że to ostatnie nasze minuty: istotnie w sąsiednich domach zastrzelili

7 Tamże, s. 174.

8 Tamże, s. 166-167. 
setki ludzi, między którymi był Mariusz Maszyński i żona Edmunda Trepki. U nas zabrali zegarki i insygnia Polonii Restituty (sądząc że są złote), masowo zgwałcili służącą i poszli. 12 sierpnia przyszły wojska niemieckie, otoczyły nasz dom, opróżnily go i spaliły. Zapędzono nas na kolej i zawieziono do Pruszkowa. Stamtąd na trzeci dzień wypuszczono, dzięki zacnemu lekarzowi, który komendantowi obozu wyperswadował, że jesteśmy chorzy na dyzenterię i możemy spowodować epidemię. Pierwszą wolną noc spędziliśmy w Stawisku, domu Jarosławów Iwaszkiewiczów, wypełnionym uchodźcami; potem dostaliśmy się do Żab, folwarku mego brata pod Błoniem: mój brat był w Rumunii, obie bratanice w powstaniu, ale zaopiekowała się nami moja bratowa. Było to na trzydziestym kilometrze od Warszawy, więc co wieczór można było z rozpaczą oglądać płonące miasto. Po paru tygodniach Niemcy zajęli dwór, trzeba było wynieść się do oficyny. Potem zajęli oficynę, trzeba było wyjechać.

Po tragedii Powstania Warszawskiego Tatarkiewiczowie dotarli w okolice Krakowa i wreszcie samego Krakowa, gdzie w 1945 r. szczęśliwie udało się im znaleźć mieszkanie oraz zdobyć profesorowi zatrudnienie na Uniwersytecie Jagiellońskim. Pozwoliło to rodzinie uzyskać pewną stabilizację, zaś profesorowi współtworzyć wraz z innymi kolejne uniwersyteckie środowisko naukowe, po tym jak współtworzył je w Warszawie, Wilnie, Poznaniu. Kraków na piętnaście lat stał się miejscem pracy profesora. Tatarkiewicz po ustaniu walk w 1945 r. starał się powrócić do rodzinnej Warszawy na uniwersytet, by i tam służyć swoją wiedzą.

Praca na Uniwersytecie Warszawskim została jednak przerwana - bo władze komunistyczne, posługując się młodymi komunistycznymi aparatczykami z Polskiej Zjednoczonej Partii Robotniczej, przygotowały profesorowi zakaz prowadzenia wykładów i pozbawily go prawa nauczania na Uniwersytecie Warszawskim. Czyniły to wszystko w sytuacji totalnego zniszczenia warstwy inteligencji narodu polskiego, katastrofy wojennej ogarniającej całą Polskę, ruiny gospodarczej, naukowej czy kulturowej.

Profesor całą swoją postawą i nauczaniem jawił się nowej władzy zainstalowanej w Polsce jako wielkie zagrożenie i przeszkoda dla nowego „porządku społecznego”, jakim miała być PRL. Należało go usunąć choćby po to, aby na jego miejsce mogli wejśćludzie marni, przeważnie pochodzenia żydowskiego, choć polskojęzyczni, gotowi do przekształcenia uniwersytetu na „kuźnie marksizmu i leninizmu”.

Haniebną rolę w realizacji planów komunistycznej władzy odegrali: Leszek Kołakowski, Henryk Holland (ojciec Agnieszki Holland), Irena Rybczyńska (matka

9 Tamże, s. 167-168. 
Agnieszki Holland), Bronisław Baczko, Henryk Jarosz, Arnold Słucki. Wystosowali oni list szkalujący profesora, domagając się jego usunięcia z uczelni, co też nastąpiło. Byli to apologeci i agenci nowego marksistowskiego barbarzyństwa niesionego Polsce; wrogowie chrześcijaństwa, wielowiekowej tradycji i kultury polskiej; ludzie kiepscy moralnie i intelektualnie, ale za to żądni władzy i apanaży, bezwzględni i służalczy. Udało się im zainstalować na uniwersytetach, mediach, instytutach kultury i używać ich do komunizowania Polaków. Nawet, gdy po latach kontestowali stalinowski marksizm - nigdy nie przestawali szczerze gardzić kulturą polską, a w sposób szczególny chrześcijaństwem, katolicyzmem, upatrując w nim naczelnego czynnika formacyjnego w duszy polskiej i zarazem swego głównego wroga.

W PRL ludzie ci znaleźli dla siebie miejsce czołowe, które jednak często zmieniali, symulując jakieś przemiany ideowe. Warunkiem ich istnienia w obszarze kultury i życia społecznego było fizyczne i duchowe unicestwienie autentycznej kultury polskiej, jej elit. Profesor Tatarkiewicz tworzył wraz z innymi autentyczne elity kultury polskiej Polski - i dlatego poszedł atak na jego osobę i jemu podobnych. Obecnie mało kto o tym pamięta, że w ataku tym uczestniczyło bardzo wielu (między innymi Jacek Kuroń, Karol Modzelewski), którzy jako studenci i młodzi marksiści siłą, wyzwiskami i obelgami zabronili profesorowi dostępu do uniwersytetu. Ludzie ci nie tylko nigdy nie wyrzekli się uczynionego przez siebie zła, nie ponieśli kary za przestępstwa, ale o zgrozo! po tzw. transformacji ustrojowej 1989 r. doczekali się zaszczytów, honorów i nagród (np. Order Orła Białego otrzymali Kołakowski, Modzelewski, Kuroń, Geremek).

Usunięcie profesora Tatarkiewicza, podobnie jak rugowanie z uczelni wielu przedwojennych uczonych (prof. Izydora Dąmbskiego, prof. Kazimierza Ajdukiewicza, prof. Tadeusza Kotarbińskiego, prof. Romana Ingardena, prof. Henryka Elzenberga, prof. Feliksa Konecznego i innych) nie było sprawą przypadku, ale celowego działania. Mordując dziesiątki tysięcy niezłomnych Polaków zbrojnie walczących z „nowym porządkiem”, stosując terror i uwięzienia, ateizację, kolektywizację, nacjonalizację i zorganizowaną walka z własnością prywatną; prowadząc zsyłki tysięcy obywateli w głąb Związku Sowieckiego realizowano likwidację Polski na rzecz zaistnienia satelity ZSRR, jakim była PRL.

Wykluczenie z życia społecznego i naukowego profesora Tatarkiewicza trwało do końca 1955 r. Dopiero po zmianach, jakie zaszły w PRL po 1956 r., profesor mógł powrócić do nauczania, zaś jego prace mogły w miarę swobodnie być rozpowszechniane, powróciły do księgarń i bibliotek. Mógł także podróżować po świecie, a wiele jego prac zostało przetłumaczonych na języki obce. On sam występował na licznych międzynarodowych spotkaniach naukowych. To wszystko sprawiło, że stał się jednym 
z najbardziej rozpoznawalnych uczonych polskich w świecie - choć w swojej ojczyźnie przez wiele lat powojennych był poniżany.

Profesor był członkiem siedemnastu towarzystw naukowych. Podróżował z wykładami do Stanów Zjednoczonych (Berkeley 1967-1968) i wielu krajów Europy. Otrzymał także szereg nagród i wyróżnień, między innymi doktoraty honoris causa Uniwersytetu Jagiellońskiego (1968) i Katolickiego Uniwersytetu Lubelskiego (1976).

W latach siedemdziesiątych profesor, mimo zaawansowanego wieku oraz chorób, cały czas oddawał się pracy, a także przeżywał radosne chwile. Jak pisał:

W 1976 roku, gdy obchodziłem jubileusz, była znów dobra chwila. Wszystko zdawało się radosne, rodzina i przyjaciele byli w pobliżu. Ale szczęście z nieszczęściem chodza na przemian, przyszła rzecz najgorsza, utrata towarzyszki życia, choroba, starość. Rok następny znów był lepszy: to był rok polskiego papieża. Wielką rzeczą w mym życiu była niezwykła dobroć i przyjaźń księdza Prymasa, kardynała Stefana Wyszyńskiego. Dzięki niej mogłem także spędzić w Pałacu Arcybiskupim cały dzień pobytu Ojca Świętego i tam z bliska zobaczyć Jego urok. Powiedziałem Mu wtedy, że na pewno nie pamięta, żeśmy się już przedtem raz spotkali. Poprawił mnie: nie raz, tylko dwa razy. Jego pamięć była lepsza od mojej. A promieniejąca z Ojca Świętego dobroć i mądrość weszła do dodatniego bilansu życia ${ }^{10}$.

Profesor Tatarkiewicz zmarł w Warszawie dnia 4 kwietnia 1980 r., tuż przed narodowym zrywem, jakim była w 1980 r. Solidarność. Jego pogrzeb odbył się 9 kwietnia. Mszę świętą za zmarłego odprawił ks. Jan Twardowski w kościele seminaryjnym przy Krakowski Przedmieściu, ciało profesora spoczęło na warszawskich Powązkach. W ostatniej drodze profesora, zgodnie z jego wolą, uczestniczyła tylko najbliższa rodzina.

Tego samego dnia w katedrze warszawskiej została odprawiona msza święta pod przewodnictwem sekretarza Episkopatu Polski biskupa Bronisława Dąbrowskiego. W koncelebrze był również rektor KUL, o. prof. Mieczysław Krąpiec. W czasie mszy odczytano list kardynała Stefana Wyszyńskiego, skierowany do syna profesora - Krzysztofa, w którym Prymas Polski pisał, że „My wszyscy w szeregach katolickich: biskupi, kapłani, alumni seminariów duchownych uważamy się za uczniów zasłużonego Profesora". Prymas Tysiąclecia przypominał także, że prace śp. profesora Tatarkiewicza

[...] były pomocniczym znakiem zdrowej filozofii, która tak optymistycznie przebijała z jasnego umysłu myśliciela i profesora. [...] Profesor umiał powiedzieć

10 Tamże, s. 187. 
współczesnym Polakom, co jest prawdziwym szczęściem dla człowieka na ziemi, co zbliża do doskonałości.

Profesor Władysław Tatarkiewicz był i jest wyjątkową postacią w kulturze polskiej i światowej. Wyborny i głęboki erudyta, znawca sztuki, wybitny estetyk - zasłynął jako znawca kultury i sztuki, historyk filozofii, humanista. Był nim bez wątpienia, lecz jego niestrudzona pracowitość, połączona z dociekliwością w dziedzinie prawdy, wierność poznanemu dobru - sprawiły, że stał się nauczycielem i wychowawcą wielu polskich pokoleń. Takim też pozostanie na długi czas przez swoją pracę i piękne dzieła życia.

Profesor żył Polską, jej właśnie służył w duchu chrześcijańskiej pokory, skromności, honoru. Jego pracowite i zarazem piękne życie, obfitujące w wiele sukcesów, ale także trudności i zmagań, bólu - było świadectwem jego ethosu, dowodem umiłowania przez niego tego, co klasyczne, co polskie i chrześcijańskie zarazem.

Będąc człowiekiem skromnym, wszystkim życzliwym, zawsze pozostawał wierny poznanej prawdzie, którą szczerze miłował. Nauka będąca jego zajęciem codziennym i zawodowym - była dla niego sposobem zdobywania prawdy, była osobistym jej przeżywaniem, także drogą jej dzielenia się oraz uczenia innych.

Tak realizował swoje człowieczeństwo tutaj na Ziemi, świadom tego że, to, co skończone i niedoskonałe, nie może mu dać pełni szczęścia. Cenił i cieszył się dobrem tego świata, cieszył się życiem, ale nie chciał dla samego świata żyć - bo widział w nim wiele zła, jednocześnie doświadczał wiele cierpień. Jak pisał „Summa summarum sądzę, że cnoty chrześcijańskie nie tylko są cnotami, ale też przeważnie życiowo skutecznymi zaleceniami" ${ }^{\prime 11}$.

Profesor za prawdę uzyskaną w poznaniu naukowym czuł się odpowiedzialny, a kiedy trzeba umiał mężnie jej bronić, nawet za cenę upokorzeń, poniżenia, biedy i wykluczenia. Nie uznawał żadnego kompromisu w dziedzinie prawdy i dobra, bo wiedział, że tam, gdzie się pojawi kompromis ze złem, kłamstwem - jest także zdrada piękna i siebie samego, jest śmierć duchowa własna i społeczna, jest potępienie i destrukcja.

Za zło nie odpłacał złem, lecz dobrem, nie tracąc nadziei na lepsze, na poprawę losu. Tym wielokrotnie wprowadzał w zakłopotanie swoich prześladowców. Nadzieja jego nie była nadzieją człowieka pysznego, lecz była nadzieją człowieka ze zdrowym rozsądkiem i zdrowym sądem o sobie i świecie.

11 Tamże, s. 178. 
Skromność profesora była szczególną - bo ściśle związaną z cnotą wielkoduszności, tą postawą duchowego wychylenia się ku sprawom najważniejszym, najcenniejszym, która wyklucza bylejakość, marność, błazenadę i blichtr, pójście z „duchem czasu", wszelką podłość. Była to skromność człowieka dojrzałego i znającego swoją wartość, szlachetnego, prawdziwego arystokraty ducha, samodzielnego w poznaniu, decydowaniu, odpowiedzialnego i roztropnego, gotowego zawsze do udoskonalenia siebie i swojego działania.

Cnota pokory była podstawą jego honoru, całej mężnej duchowości i pracy. Wielkoduszność i skromność nie pozwalały mu na chorą ambicję oraz jakiekolwiek formy poniżania drugiego człowieka, raczej skłaniały do szukania w nim dobra, do dostrzegania zasadnych racji oraz prawdy. Nie był więc człowiekiem, który za wszelką cenę starał się być wszędzie pierwszym, adorowanym, lecz takim, który dobrze spełniał to, co stoi przed nim jako jego własne i właściwe zadanie.

Był prostolinijnym i dobrym, jednocześnie chciał sprawiać, by inni stawali się dobrzy, zwłaszcza przez poznaną prawdę, przez umiłowanie autentycznego dobra, przez dostrzeżenie i przeżycie piękna - oto zasady, które kierowały życiem profesora Władysława Tatarkiewicza, wybitnego Polaka, nauczyciela i wychowawcy wielu pokoleń.

Streszczenie: W artykule pragnę ukazać losy życiowe prof. Władysław Tatarkiewicza i ich wpływ na jego formację intelektualną, a także dokonywane przez niego wybory moralne, intelektualne. Był on wychowawcą i nauczycielem wielu polskich pokoleń intelektualistów, a jego opracowania z dziedziny etyki, historii filozofii oraz estetyki stanowią wielki skarb intelektualnej kultury polskiej. Do dnia dzisiejszego w kulturze polskiej mało znaną jest sprawa roli jaką w jego formacji intelektualnej odegrała religia katolicka i sama polska kultura narodowa. Droga życia profesora Władysław Tatarkiewicza była złożona, bogata, moralnie piękna, a w swojej treści osadzona w polskości i tradycji narodowej, katolickiej. Zasadniczą rolę w formacji Tatarkiewicza odegrało obok domu rodzinnego, żyjącego kulturą szlachecką, ziemiańską - klasyczne gimnazjum. Ukończył je w Warszawie w wieku lat siedemnastu. Przez zapoznanie się z greką, łaciną oraz literaturą klasyczną rozmiłował się w greckim ideale kalokagatheii. Tam też swoją uwagę zwrócił ku sztuce, architekturze oraz rozważaniom z dziedziny estetyki i filozofii. Jak pisał "Wychowałem się w domu wierzącym. Prawdy wiary były dla mnie w dzieciństwie i później taką samą rzeczywistością jak fakty otaczającego mię świata. Niemało ułatwiły mi życie, choć czasem myślę, że wiara religijna jest rzeczą, którą należy samemu zdobyć, a nie dziedziczyć" (Wspomnienia, s. 120).

Słowa kluczowe: Władysław Tatarkiewicz, historia filozofii, etyka, biografia, tradycje narodowe i katolickie 


\section{Bibliografia}

Charisteria. Rozprawy filozoficzne złożone $w$ darze Władysławowi T. $w$ siedemdziesiąta rocznicę urodzin, Warszawa1960.

Dembowski B., O profesorze Władysławie Tatarkiewiczu (1886-1980). Wspomnienia ucznia, „Filo-Sofija", 13-14 (2011) s. 433-450.

Dziemidok B., Tatarkiewicz Władysław, w: Powszechna encyklopedia filozofii, t. 9, red. A. Maryniarczyk, Lublin 2008, s. 372-376.

Jaworski M., Władysław Tatarkiewicz, Warszawa 1975.

Tatarkiewiczowie T. i W., Wspomnienia, Warszawa 1979. 